九州大学学術情報リポジトリ

Kyushu University Institutional Repository

\title{
Molecular Cloning of Nucleotide Sequence of a Neutral Cellulase Gene of Thermophilic Clostridium sp. F-3
}

\section{Hara, Toshio}

Microbial Genetic Division, Institute of Genetic Resources, Faculty of Agriculture, Kyushu University

Kume, Sigeru

Laboratory of Food Technology, Department of Food Science and Technology, Faculty of Agriculture, Kyushu University

Fujio, Yusaku

Laboratory of Food Technology, Department of Food Science and Technology, Faculty of Agriculture, Kyushu University

\section{Ishizaki, Ayaaki}

Laboratory of Microbial Engineering, Department of Food Science and Technology, Faculty of Agriculture, Kyushu University

他

https://doi.org/10.5109/23963

出版情報: 九州大学大学院農学研究院紀要. 36 (1/2)，pp.13-22，1991-10. Kyushu University バージョン：

権利関係: 


\title{
M olecular Cloning of $\mathrm{N}$ ucleotide Sequence of a Neutral Cellulase Gene of Thermophilic Clostridium sp. F-3
}

\author{
Toshio Hara ${ }^{1 *}$, Sigeru Kume ${ }^{2}$, Yusaku Fujio ${ }^{2}$, \\ Ayaaki Ishizaki ${ }^{3}$ and Seiya Ogata ${ }^{1}$ \\ 'Microbial Genetic Division, Institute of Genetic Resources, \\ ${ }^{2}$ Laboratory of Food Technology and ${ }^{3}$ Laboratory of Microbial \\ Engineering, Department of Food Science and Technology, \\ Faculty of Agriculture, Kyushu University 46-09, Fukuoka 812, Japan
}

(Receired March 15, 1991)

\begin{abstract}
A 1.7-kb Hind111 fragment of Clostridium DNA cloned in Escherichiacoli was shown to direct the synthesis of a neutral cellulase. The optimum $\mathrm{pH}$ was 6.5 for the enzyme encoded on the 1.7-kb DNA fragment and 7.5 for the enzyme produced by transformant was slightly decreased from $70 \mathrm{C}$ to $65 \mathrm{C}$. The neutral cellulase gene was located on a $1.2-\mathrm{kb}$ DNA fragment as a functional state, derived from the $1.7-\mathrm{kb}$ DNA fragment, and the nucleotide sequence was determined. The coding sequence showed an open reading frame encoding 552 bp corresponding to 184 amino acid residues with molecular weight of 20,378 daltons. However, the regulatory sequences and/or N-terminal region of the encoded polypeptide were not detected in the sequence encoded the neutral cellulase gene. The enzyme encoded on the $1.7-\mathrm{kb}$ fragment might consist of a half region (C-terminal region) of the mature enzyme, and be expressed by lac $\mathrm{Z}$ promoter of vector, pUC9.
\end{abstract}

\section{INTRODUCTION}

Cellulase (1, 4- $\beta$-D-glucan Glucanohydrolase, EC 3. 2. 1. 4) extracellularly produced by various microorganisms has been the subject of many enzymological studies as well as being applied for the biodegradation of cellulose materials. Cloning of the cellulase genes from these organisms would be useful not only for increasing the enzyme productivity but also for obtaining the informations on structure/function relationship of these enzymes.

The cellulase genes of Clostridium thermocellum (Cornet et al., 1983a and 1983b), Cellulomonas fimi (Whittle et al., 1982 ; Gilkes et al., 1984), Trichoderma reesei (Shoemaker et al., 1983), Thermoanerobacter cellulolyticus (Honda et al., 1987), Bacillus subtilis (Koide et al., 1986) and alkalophilic Bacillus strains (Sashihara et al., 1984 ; Fukumori et al., 1986b) have already been cloned, and recently, the nucleotide sequences of the cellulase gene of C. thermocellum (Beguin et al., 1985 ; Grepinet and Beguin, 1986 ; Joliff et al., 1986), Cellulomonas uda (Nakamura et al., 1986) and Pseudomonas fluorescens subspp. cellulosa (Hall and Gilbert, 1986), the $\beta$-glucanase gene of C. acetobutylicum (Zappe et al., 1988) and B. subtilis (Murphy et al., 1984 ; Nakamura et al., 1987) and the alkaline cellulase gene of the alkalophilic Bacillus sp. (Fukumori et al., 1986a and 1986b) and Streptomyces (Nakai et al., 1988) were determined.

\footnotetext{
*Cossesponding author
} 
However, nothing is known about the structure of DNA regions controlling gene expression or about signal sequences governing protein transport in gram-positive thermophiles. In order to increase cellulase production and understand the structure and function of cellulase(s) of this strain, we cloned a neutral cellulase gene of thermophilic Clostridium sp. F-3 in Escherichia coli JM83. The present paper deals with the cloning and expression of a neutral cellulase gene in E.coli and the nucleotide and deduced amino acid sequences of the cloned cellulase gene derived from thermophilic Clostridium.

\section{MATERIALS AND METHODS}

\section{Bacterial strains and plasmid}

Clostridium sp. F-3, a producer of alkaline and neutral cellulases, isolated from sewage sludge (Kume and Fujio, 1986). After complete consumption of cellulose in the medium, cells were harvested for the DNA preparation. Escherichia coli K12 strain JM83 and recombinant clones were cultivated in Luria-Bertani (LB) medium at 37 C. When necessary, $50 \mu \mathrm{g} / \mathrm{ml}$ ampicillin (Amp) was 'added to the medium. Plasmid pUC9 was used as a vector for the cloning and in DNA sequencing.

\section{DNA preparation and construction of recombinant DNA}

Chromosomal DNA was prepared from the isolated Clostridium strain F-3 by the method of Saito and Miura (1963). PlasmidDNAs were extracted from E. coli transformants by the alkaline lysis procedure (Birnboim and Doli, 1979). Chromosomal DNA of the Clostridium strain F-3 was partially digested with HindIII and ligated to dephosphorylated-HindIII-cut pUC9. The ligated DNA was used to transform competent cells of strain JM83 (Cohen et al., 1972). Cellulase-producing transformants were selected by the Congo-red method as described by Cornet et al. (1983a).

\section{Enzyme assay}

For the cellulase assay, the amount of reducing sugars produced by the enzyme reaction was measured. Reaction mixture contained $0.1 \mathrm{M}$ potassium phosphate buffer $(\mathrm{pH} 7.0), 1.0 \%$ carboxymethyl cellulose (CMC) and suitable amount of crude enzyme solution. The mixture was incubated at $60 \mathrm{C}$ for $10 \mathrm{~min}$, then enzyme reaction was stopped by boiling for $5 \mathrm{~min}$. The reducing sugars were determined by the method as described by Sumner and Somer (1944). One unit of enzyme activity was defined as 1 $\mu \mathrm{mol}$ glucose-equivalent reducing sugars released per minute.

\section{DNA labeling and hybridization of DNA digests}

DNA was labeled, as nonradioactive system, by random primed incorporation of digoxigenin-labeled deoxyuridine-triphosphate (Feinberg and Vogelstein, 1983). The hybridization technique used was essentially the same that described previously (Southern, 1975). After hybridization, the hybrids were detected with enzyme immunoassay by using DIG-ELISA method under the conditions recommended by the supplier (Boehringer Mannheim GmbH, West Germany). 


\section{DNA sequencing}

This was done by the dideoxy chain termination method (Sanger et al., 1977), specific restriction fragments being cloned into pUC9 vector for dideoxy sequencing by using $\alpha^{-32} \mathrm{PdCTP}$.

\section{Reagents}

All restriction enzymes used were obtained from commercial suppliers and were used according to manufactures' recommendations. T4 DNA ligase and M13 Sequencing kit were from Takara Shuzo Co., Ltd. $\alpha^{-32} \mathrm{P} \mathrm{dCTP}$ was obtained from Amersham International Plc., UK. E.coli DNA polymerase I and nonradioactive DNA labeling and detection kit were purchased from Boehringer Mannheim $\mathrm{GbmH}$, West Germany. The CMC, with a degree of substitution of 0.65 and an average molecular weight of 110,000 was obtained from Nakarai Chemical Co., Kyoto, Japan. Congo-red was purchased from Merck Co., Ltd.

\section{RESULTS}

\section{Cloning of a cellulase gene in E. coli}

The chromosomal DNA of the isolated Clostridium strain F-3 and plasmidpUC9 DNA were digested with HindIII restriction endonuclease and ligated with T4 DNA ligase. The ligation mixture were used to transform into E.coli JM83 and about $10^{4}$ Amp' transformants per $\mu \mathrm{g}$ of DNA were obtained. Only one transformant produced a shallow crater around colonies on CMC-containing LB plate. The cellulase-producing transformant was identified by a clear zone around the colonies on CMC-Congo red plates. The plasmid DNA was isolated from this transformant and designated pIK1. The pIK1 contained 1.7-kilobases $(\mathrm{kb})$ fragment and could transform E.coli to Amp' $\mathrm{Cel}^{+}$at high frequency. Therefore, we concluded that this fragment contained the cellulase gene. Figure 1 shows the restriction map of pIK1. The 1.7-kb DNA fragment of pIK1 was found to possess two sites with HincII and three sites with Eco RI and HindIII.

\section{Some enzymatic properties of Clostridium cellulase produced by E. coli}

The authentic enzyme prepared from Clostridium sp. F-3 indicated cellulolytic activity on various substrates, while the enzyme produced by transformant only on a $\mathrm{CMC}$ as a substrate (Table 1). The effects of $\mathrm{pH}$ and temperature on the cellulase activity were determined by measuring the reducing sugars derived from CMC (Fig. 2). The optimum $\mathrm{pH}$ was 7.5 and 10.0 for the authentic enzyme prepared from Clostridium sp. F-3, and 6.5 for the enzyme encoded by the plasmidpIK1 (Fig. 2A). The thermal stability of the enzyme prepared from Clostridium sp. F-3 was quite stable up to $70 \mathrm{C}$, while that of transformant up to $65 \mathrm{C}$ (Fig. 2B). Both enzymes produced by Clostridium sp. F-3 and the transformant were rapidly inactivated at $75 \mathrm{C}$ with similar profile. These results support that the neutral cellulase gene derived from the strain Clos. tridium sp. F-3 was cloned and expressed in E. coli JM83.

\section{Homology of plasmid pIK1 with chromosomal DNA}

Location of the cellulase gene in the $1.7-\mathrm{kb}$ fragment was studied by constructing 
smaller derivatives as shown in Fig. 3. The transformant carrying either pIKH1 or pIKH2 exhibited a level of cellulase activity similar to that of the original clone. The transformant carrying pIKH5, which deleted the HincII-HindIII fragment from the pIK1, did not, however, show the enzyme activity. These results suggest that the gene might be located on the fragment between HincII and HindIII sites (Fig. 3). To confirm that the 1.7-kb DNA fragment was derived from Clostridium sp. F-3, the 1.2$\mathrm{kb}$ HincII-HindIII fragment of pIKl was isolated, labeled by random primed incorporation of digoxigenin-labeled deoxyuridine-triphosphate and hybridized to chromosomal DNAs by the method of Southern (1975). As shown in Fig. 4, the labeled probe

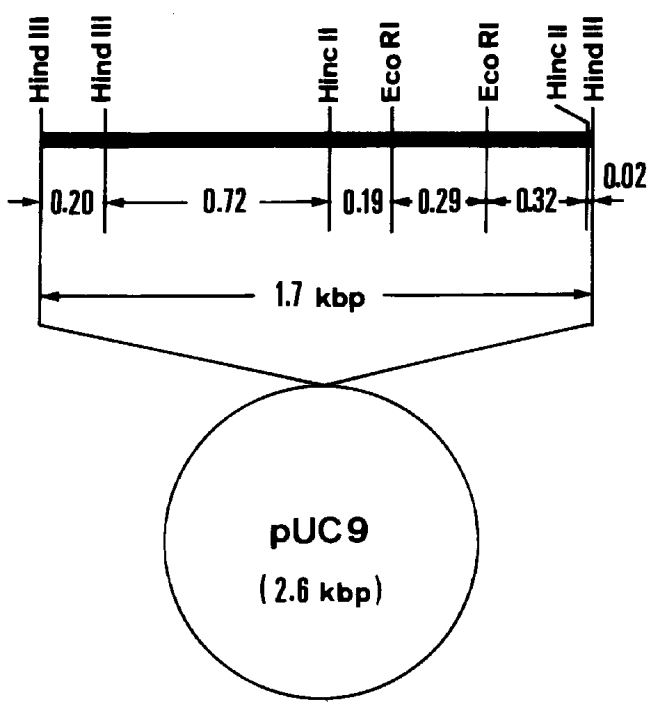

Fig. 1. Restriction map of plasmid plkl.

Restriction sites are indicated, an their coordinates are given in $\mathrm{kb}$. The thick line shows the cloned 1.7-kb fragment from Clostridium sp. F-3, and the thin line the vector, pUC9.

Table 1. Comparison of cellulase productivity on various substrates between Clostridium sp. F-3 and E. cloi JM83 (pIK1)

\begin{tabular}{lcc}
\hline Substrate & Clostridium sp. F-3 & E. coli JM83 (pIK1) \\
\hline CM-cellulose" & 1.16 & 0.64 \\
Filter paper $^{\mathrm{b}}$ & 0.27 & $\mathrm{ND}_{\mathrm{c}}$ \\
Avicel $^{\mathrm{b}}$ & 0.16 & $\mathrm{ND}_{\mathrm{c}}$ \\
Cotton $^{\mathrm{b}}$ & 0.03 & $\mathrm{ND}_{\mathrm{c}}$ \\
Laminarin" $^{\mathrm{a}}$ & 0.07 & $\mathrm{ND}_{\mathrm{c}}$
\end{tabular}

The values are expressed as units per milliliter of enzyme solution.

"1 unit-1 $\mu$ mole of glucose released per min.

${ }^{\mathrm{b}} 1$ unit-1 $\mu$ mole of glucose released per hr.

'Not detected. 

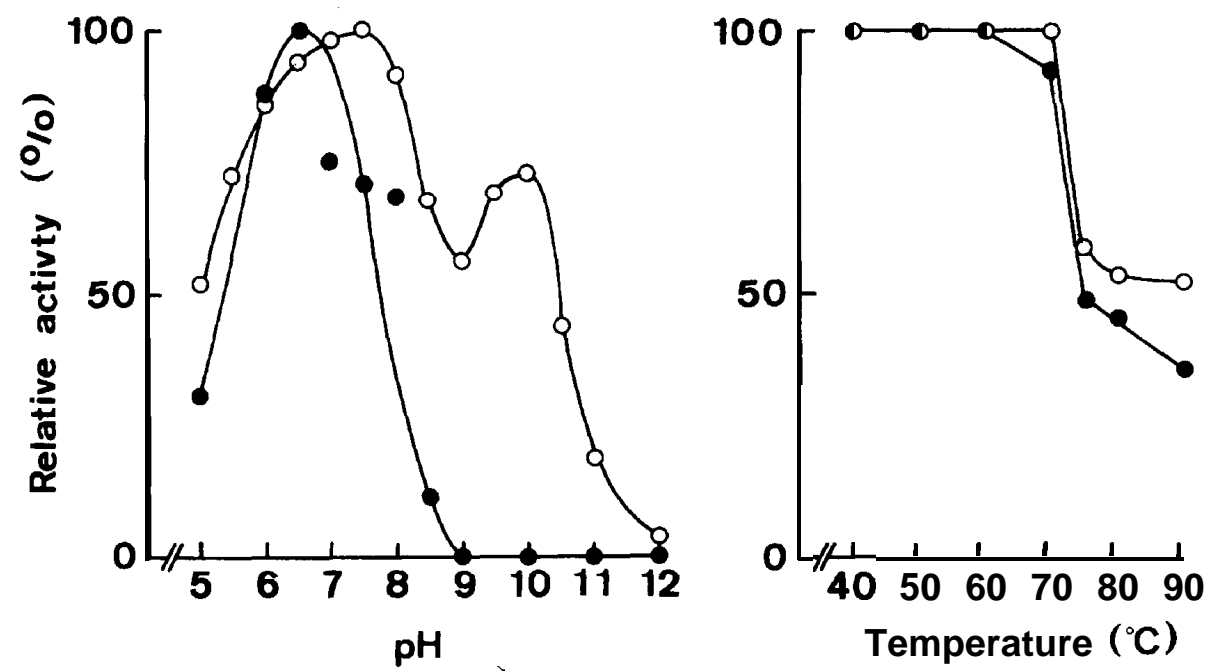

Fig. 2. Comparison of optimum $\mathrm{pH}$ and thermal stability produced by Clostridium sp. F-3 (•) and E. coli JM83 (pIK1) (O).

(A) The optimum $\mathrm{pH}$ was measured by using $\mathrm{CMC}$ as a substrate at $60 \mathrm{C}$ for $10 \mathrm{~min}$ and the following buffer systems were used :0.05 $\mathrm{M} \mathrm{CH}_{6} \mathrm{COOH}_{-} \mathrm{CH}_{3} \mathrm{COONa}(\mathrm{pH} 4-6)$, $0.05 \mathrm{M} \mathrm{KH}_{2} \mathrm{PO}_{4}-\mathrm{K}_{2} \mathrm{HPO}_{4}(\mathrm{pH} 6-8), 0.05 \mathrm{M} \mathrm{KH}_{2} \mathrm{PO}_{4}-\mathrm{Na}_{2} \mathrm{~B}_{4} \mathrm{O}_{7}(\mathrm{pH}$ 8-9) and $0.05 \mathrm{M} \mathrm{Na}$ $\mathrm{B}_{4} \mathrm{O}_{7}-\mathrm{NaOH}(\mathrm{pH} 9-12)$. (B) The thermal stability was measured after incubation at indicated temperature for $10 \mathrm{~min}$, and then enzyme activity was measured by using CMC as a substrate.

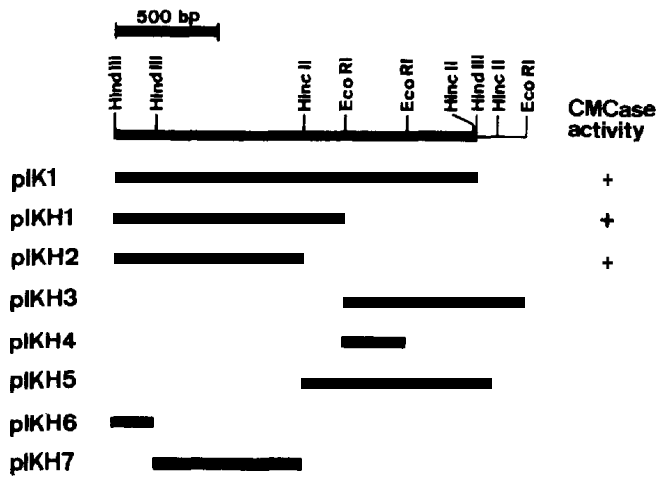

Fig. 3. Deletion analysis of cellulase gene encoding on $1.7-\mathrm{kb}$ fragment. Thick line indicates DNA insert derived from $1.7-\mathrm{kb}$ DNA fragment. 


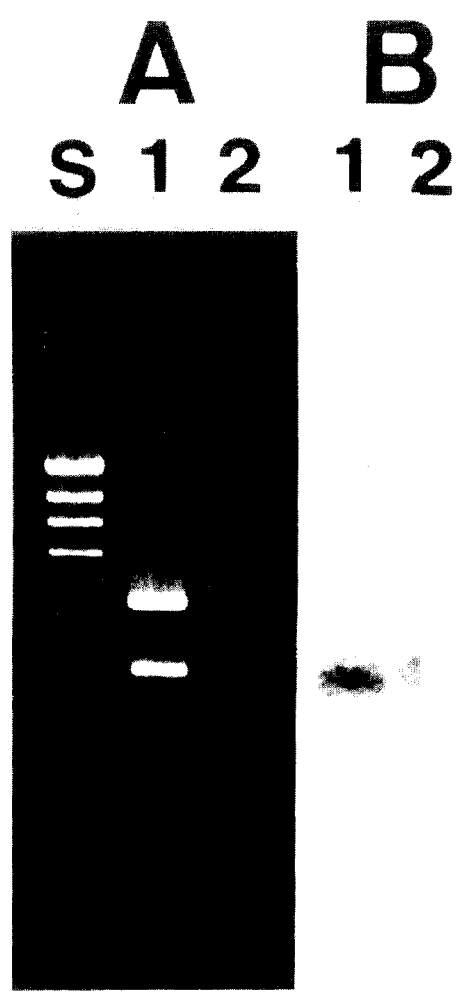

Fig. 4. (A) Agarose gel electrophoresis of digsts of pIKl (lane 1) and Clostridium sp. F-3 chromosomal DNA with Hind III (lane 3).

The DNA was denatured, transferred to a nitrocellulose filter and then hybridized with the $1.7-\mathrm{kb}$ insert DNA fragment labeled by random primed incorporation of digoxigenin-labeled deoxyuridine-triphosphate. Hind III fragments of phage $\lambda$ DNA (lane S) were used as molecular size markers.

Hybridization patterns with digoxigenin-labeled probe (B).

hybridized strongly to the HindIII digests derived from chromosomal DNA prepared from the isolated strain Clostridium sp. F-3.

DNA sequence

Subcloning of the $1.7-\mathrm{kb}$ insert of pIK1 revealed that the cloned cellulase gene was located on a 1.2-kb HincII-HindIII fragment. As shown in Fig. 5, the nucleotide sequence of the $1.2-\mathrm{kb}$ insert DNA of pIKH2 was determined by the chain-terminating dideoxy method (1977). Though the strategy is not shown, the nucleotide sequence was determined for both strands using numerous restriction fragments to give enough overlapping regions. The pIKH2 contained a single open reading frame of 552 base pairs (bp), which encoded 184 amino acid residures (Fig. 5). The relative molecular mass calculated from the DNA sequence was 20,378 daltons. On this coding frame, 
there were two initiation codon (ATG at positions 8-10 and 11-13), but we could not detect the potential initiation codon preceded by a ribosome binding site. However, a palindromic repeat sequence of $5 \mathrm{bp}$ was found $44 \mathrm{bp}$ downstream of the termination codon, which seemed to resemble a p-independent terminator. We therefore concluded that only C-terminal region of the mature cellulase gene located on the 1.7-kb HindIII DNA fragment derived from Clostridium sp. F-3 was cloned, and only a limited segment of the authentic enzyme was expressed by lacZ promoter of pUC9 in E. coli JM83.

5' AAGCTTAATGATGAATTCATGITTGGAACCGCTACCGAAGTATCAGATTGAGGGTGGGGA

SerLeuMetMetAsnSerCysLeuGluProLeuProLys TyrGInI l eGluGl yGl yAs

TACGGGAATACATGGTATAAGTGGTGCCAGGCAGGACGTATCAAGGACTCCAGCAGCTG 120 pThrGl yAsnThrTrpTyrLys TrpCysG1nAl aGlyArgI l eLysAspSerSerSerCy

TATCACTGCATGTGACCATTGGACAGGTGAGGAGGATACGGACCTGTTGAAGACTTGG 180 sI le ThrAl aCysAspH i sTrpThrGl yGluGluAspThrGluLeuLeuLysAsnLeuGl

AGTTCAAACCCACAGAATGAGTCTTGAGTGGAGCAGAATAGAGCCTTCCAGGGGCAATT 240 yValGlnThrHi sArgMetSerLeuGluTrpSerArgI l eGluProSerArgGl yL ys Ph

TTCCGATGACGCAATGAACATTACAGAGATGAGATTAAGCTITTGGATGCAAGCGGAA 300 eSerAspAspAl aMetLy SH i sTyrArgAspGlu I l eL ysLeuLeuAspAl aSerGl yAs

CGAGCTTGTAATGAGGGGCATGCGTGATATTTCAGCAATAGATTTGGTTAAGAAATAAA 360 nGluLeuVa IMetArgGl yMetArgAsp I l eSerAlaI leAspLeuValLysGluI l eLy

AATCGGATGGATTTGGGAATACTTTGGATGCTCCTACAGAGACTGCCTGGGGAATCC 420 sI leGlyTrpAsnLeuGl yAsnThrLeuAspAl aProThrGluThrAl a TrpGl yAsnPr AAGGACAGCCAAGGCAATGATAGAAAGGTAAGGGAATGGGCTITAATGCCGTCAGAGT 480 oArgThrAl aLysAl aMet I leGluLysVal ArgGluMetGl yPheAsnAlaValArgVa

GCCTGITACCTGGGATACGCACATCGGACCTTCTCCGGACTATAAAATTGACGAAGCATG 540 IProValThrTrpAspThrHisI leGlyProSerProAspTyrLys I leAspGluAlaTr

GCTGACACAGAGTTGAGGAGTGGTAACTATGTTCTTGACTGCGGATCATAAATGITCA 600 pLeuThr G nSer***

CCATGACAATACATGGATTATACCTACATATGCCAATGAGCAAAGGAGTAAAGAAAAACT $\mathbf{6 6 0}$ TGTAAAAGTTGGCAACAAATAGGCAACCCCGITTAAAGATTATGACGACCATTTGT 720 GITGAGACAATGACCGGAACGAGAGAACCTAGGTCACCTATGGAATGGATGGGCGG 780 ACCGTATGAAACCGAGATGCGATAAACAGATTTAATTTGCCGCTGTTAATACCATCAG 840 AGCAAGCGGCGGAATAACGATAAAGATTCATACTGGTCGACCAATCGGCAACCGCCC 900 TGGATGTTGCATTAAACGCCTTGTCATTCCGACAATCGGACAGGAGAGTCATAGTATC 960 CATACATGCTTATTCACCGTATTCTTTGCTATGGATGTC 3'

Fig. 5. Nucleotide sequence of the cellulase gene from Clostridium sp. F-3.

The DNA sequence of the coding strand is given from 5' to 3', numbered from nucleotide 1 at the cloning site. The predicted amino acid sequence is given below the DNA sequence. 
Amino acid sequence of the predicted cellulase gene was compared with a number of protein sequences registered in Genbank with use of the homology search system of GENAS (Kuhara et al., 1984). No convincing homology could be found among various cellulases ; endoglucanases A, B and D from C. thermocellum and alkaline cellulase and $\beta$-glucanase from B. subtilis, with the neutral cellulase of Clostridium sp. F-3, these cellulases for which complete sequence data are available.

\section{DISCUSSION}

We have cloned a neutral cellulase gene of Clostridium sp. F-3, produced two kinds of cellulase with the optimum $\mathrm{pH}$ at 7.5 and 10.0 in the process of fementative solubilization of sewage sludge by mix culture (Kume and Fujio, 1986). The authentic enzyme prepared from Clostridium sp. F-3 released reducing sugars from various substrates, while the enzyme produced by transformant degraded only CMC as a substrate (Table 1). The optimum $\mathrm{pH}$ and thermal stability of the enzyme produced by transformant were slightly decreased as compared with the authentic enzyme prepared from Clostridium sp. F-3 (Fig. 2). These results, therefore, indicate that the cloned cellulase gene is corresponding to a neutral CMCase, and it is very interesting to reveal the different features of both enzymes. The nucleotide sequence of subcloned 1.2-kb DNA fragment of pIKH2 contained a single open reading frame of $552 \mathrm{bp}$, which was corresponding to 20,378 as a relative molecular mass. However, we could not detect any regulatory sequences of promoter on the upstream of the open reading frame encoding the neutral cellulase gene of Clostridium sp. F-3 (Fig 5). On the other hand, Kume and Fujio (1986) reported that the molecular mass of the purified neutral cellulase of Clostridium sp. F-3 was about 40,000 by SDS-PAGE. Based on these results, we concluded that the region of the cloned cellulase gene is corresponding to a half size containing the C-terminal region of the matured enzyme and that the cellulolytic enzyme activity was expressed by lac $Z$ promoter of vector pUC9. It, furthermore, contained 4 cystein residues to be formable disulfide bridges in a polypeptide (Fig. 5), so that the enzyme produced by transformant might indicate the thermal stability up to at $65 \mathrm{C}$. In fact, the enzyme had been shown to be insensitive to oxidation or to SH-modifying reagents (Kume and Fujio, data not shown). It must, therefore, be assumed that free SH groups either are not required for enzymatic activity or are protected against chemical modification.

No convincing homology could be found among the complete sequences of the cloned cellulase genes by GENAS, but only a Ala-Ser-Gly-Asn-Glu-Leu-Val-Met segment was detected as homologous region with endo-glucanase A of C. thermocellum (Beguin et al., 1985) and endo- $\beta-1,4$-glucanase of B. subtilis (Murphy et al., 1984). However, we have no information concerning with the relationship between structure and function of cellulolytic enzymes because of the insoluble crystalline nature of cellulose. Further comparison of the amino acid sequence of the Clostridium cellulase with those of Clostridium cellulases and amino acid residue conversion by in site mutagenesis should provide information on the structure determining the optimum $\mathrm{pH}$ and thermal stability for the enzyme activity. 


\section{Acknowledgements}

We are indebted to Mr. H. Kawauchi for his help in sequencing and also to Dr. S. Kuhara for the computer search of protein sequences.

\section{REFERENCES}

Beguin, P., P. Cornet, and J. P. Aubert 1985 Sequence of a cellulase gene of the thermophilic bacterium Clostridium thermocellum. J. Bacteriol., $162: 102-105$

Birnboim, H. C., and J. Doli 1979 A rapid alkaline extraction procedure for screening recombinant plasmid DNA. Nucl. Acids Res., '7: 1513-1523

Cohen, S. N., A. C. Y. Chang, and L. Hsu 1972 Nonchromosomal antibiotic resistance in bacteria : genetic transformation of Escherichia coli by R-factor DNA. Proc. Natl. Acad.Sci. U.S. A., $69: 2110$ 2114

Cornet, P., J. Millet, P. Beguin, and J. P. Aubert 1983a Characterization of two cel (cellulose degradation) genes of Clostridium thermocellum coding for endo-glucanases. Bio/Technology, $1: 589-594$

Cornet, P., D. Tronik, J. Millet, and J. P. Aubert 1983b Cloning and expression in Escherichia coli of Clostridium thermocellum genes coding for amino acid synthesis and cellulose hydrolysis. FEMS Microbiol. Lett., $16: 137-141$

Feinberg, A. P. and B, Vogelstein 1983 A technique for radiolabeling DNA restriction endonuclease fragments to high specific activity. Anal. Biochem., $132: 6^{-13}$

Fukumori, F., T. Kudo, Y. Nakanishi, and K. Horikoshi 1986a Molecular cloning and nuclease sequence of the alkaline cellulase gene from the alkalophilic Bacillus sp. strain 1139. J. Gen. Microbiol., $132: 2329-2335$

Fukumori, F., N. Sashihara, T. Kudo, and K. Horikoshi 1986b Nucleotide sequence of two cellulase genes from alkalophilic Bacillus sp. strain N-4 and their strong homology. J. Bacteriol., 168 : 479485

Girkes, N. R., D. G. Kilburn, M. L. Langsford, R. C.Jr. Miller,W. W. Wakarchuk, R. A. J. Warren, D. J. Whittle, and K. R. Wong 1984 Isolation and characterization of Escherichia coli clones expressing cellulase genes from Cellulomonas fimi. J. Gen. Microbiol., $130: 1377-1384$

Grepinet, 0. and P. Beguin 1986 Sequence of the cellulase gene of Clostridium thermocellum coding for endoglucanase B. Nucl. Acids Res., 14: 1791-1779

Hall, J. and H. J Gilbert 1988 The nucleotide sequence of a carboxymethylcellulase gene from Pseudomonas fluorescens subsp. cellulosa.Mol. Gen. Genet., $213: 112-117$

Honda, H., H. Naito, M. Taya, S. Iijima, and T. Kobayashi 1987 Cloning and expression in Escherichia coli of a Thermoanaerobacter cellulolytius gene coding for heatstable $\beta$-glucanase. Appl. Mi. crobiol.Biotechnol., $25: 480-483$

Joliff, G., P. Beguin, and J. P. Aubert 1986 Nucleotide sequence of the cellulase gene celd encoding endoglucanase D of Clostridium themzocellum. Nucl. Acids Res., 14: 8605-8613

Johnson, W. C., C. P. Jr. Moran, and R. Losick 1981 Two RNA polymerase sigma factors from Bacillus subtilis discriminate between overlapping promoters for a developmentally regulated gene. Nature (London), $302: 800-804$

Koide, Y., A. Nakamura, T. Uozumi, and T. Beppu 1986 Molecular cloning of a cellulase gene from Bacillus subtilis and its expression in Escherichia coli. Agric. Biol. Chem., 50 : 233-237

Kuhara, S., F. Matsuo, S. Futamura, A. Fujita, T. Shinohara, T. Takagi, and Y. Sakaki 1984 GENAS : a database system for nucleic acid sequence analysis. Nucl. Acids Res.,12 : 89-99

Kume, S. and Y. Fujio 1986 Isolation and purification of the cellulase produced by the sewage sludge ferment microbes. Abstracts of papers, the Annual Meeting of Agricultural Chemical Society of Japan, Kyoto, Apr p. 268

McLaughlin, J. R., C. L. Murray, and J. C. Rabinowitz 1981 Unique features in the ribosome binding 
site sequence of the gram-positive Staphylococcus aureus $\beta$-lactamase gene. J. Biol. Chem., 256 : 11283311291

Murphy, N., D. J. McConnel, and B. A. Cantwell 1984. The DNA sequence of the gene and genetic control site for the excreted in Bacillus subtilis enzyme $\beta$-glucanase. Nucl. Acids Res., 12 : 5355 5367

Nakai, R., S. Horinouchi, and T. Beppu 1988 Cloning and nucleotide sequence of a cellulase gene, $\operatorname{cas} A$, from an alkalophilic Streptomyces strain. Gene, $65: 229-238$

Nakamura, K., N. Misawa, and K. Kitamura 1986 Sequence of a cellulase gene of Cellulomonas uda CB4. J. Biotechnol., 4: 247-254

Nakamura, A., T. Uozumi, and T. Beppu 1987 Nucleotide sequnce of a cellulase gene of Bacillus subtilis. Eur. J. Biochem., 164 : 317-320

Saito, H., and K. Miura 1963 Preparation of transforming deoxyribonucleic acid by phenol treatment. Biochim. Biophys. Acta, $72: 619-629$

Sanger, F., S. Nickeen, and A. R. Coulson 1977 DNA sequencing with chain-terminating inhibitors. Proc. Natl. Acad.Sci. U.S. A, 74 : 5463-5467

Sashihara, N., T. Kudo, and K. Horikoshi 1984 Molecular cloning and expression of cellulase genes of alkalophilic Bacillus sp. strain N-4 in Escherichia coli.J.Bacteriol., 158 : 503-506

Shoemaker, S., V. Schweickaert, M. Ladner, D. Gelfand, S. Kwok, K. Myambo, and M. Innis 1983 Molecular cloning of exo-cellobiohydrolase I derived from Trichoderma reesei strain L27. Biol Technology, 1 : 681-696

Sumner, J. R. and G. F. Somers 1944 Laboratory experiments in biological chemistry. p34-35, Academic Press Inc, NewYork

Southern, E. M. 1975 Detection of specific sequences among DNA fragments separated by gel electrophoresis. J. Mol. Biol., 98 : 503-517

Whittle, D. J., D. G. Kilburn, R. A. J. Warren, and R. C. Jr Miller 1982 Molecular cloning of a Celiulomonas fimi cellulase gene in Escherichia coli. Gene, 17 : 139-145

Zappe, H., W. A. Jones, D. T. Jones, and D. R. Woods 1988 Structure of an endo- $\beta-1,4$-glucanase gene from Clostridium acetobutylicum P262 showing homology with endo-glucanase genes from Bacillus spp. Appl. Environ. Microbiol., 54 : 1289-1292 